論

福 田 精 教 授 退 官記念論 文

\title{
むち打ち損傷例でみられる内耳障害型「めまい」
}

一頸筋緊張方進との関連において一

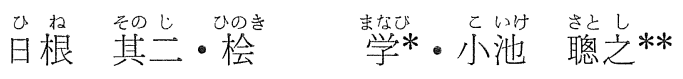

I はじめに

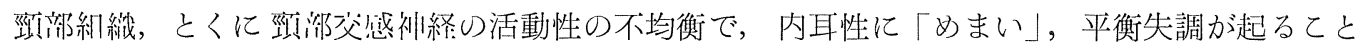
は，メニエール病などを対象として多くの研究がある (Wildhagen 1958, 朴沢 1959, Maspetiol 1960，時田 1965）。一方，外傷性頸部症候を示す例の「めまい」が， ‘……組織とくにその 部の脊柱起立筋の緊張六進でひきおてされることについては, 既に 教室からしばしば報告されてい

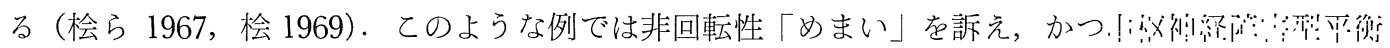

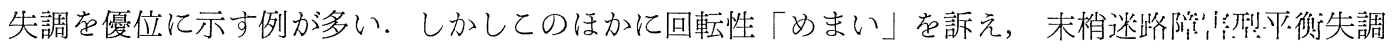
を呈する症例が存在する. 前者の「めまい」, 平衡失調の発現機転については, 同時に存する視床下

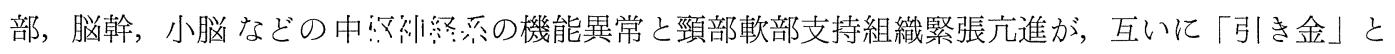
「まと」の関係をなして，「めまい」を構成するものと理解してきた，とてろで，むち打ち損傷例の 内耳性「めまい」，干衡人洞の発現機転を同じような考え方，すなわち 頸部軟部支持組織々内耳が 互いに「引き金」と「まと」の関係をなして「めまい」構成に関与すると理解してよいかどうか, この問題を判定する資料はなお充分でない. 最近, 協同研究者の福井は, 正常ウサギの深网项笃に 片側性に procaine 法射を行ない, 而侧彷倠の活動性の不均衡を来すよう操作すると, 眼振が出現 するてとを明かにしている，そしてての際の眼振はその性格が多彩であり（水平，回旋，垂直いず れの型の眼振も出現しうる), かつその方向も variable である（福井 1971）. ところで片側迷路が

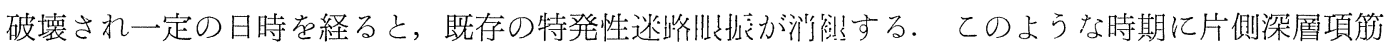

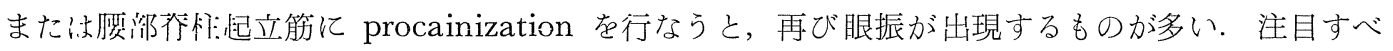
きは，乙の際の眼振が水平性であり，片：……等後日が浅いと多くは健耳側むきであるととであ る（福井, 桧ら 1970).すなわち, 項筋または腰部脊柱起立筋への操作で, 潜在性の特発性前庭性 眼振が再現した形をとることが注目される。もちろん，上述のウサギの成績を直ちにヒトのむち打 ち損傷例にあてはめて考えるてとには飛躍があろう。しかし以上の成績より, 頸部軟部支持組織緊 張㠵進で誘発される内耳性「めまい」の発現機序に関して，次の仮説か設定されてもよいように思

Neurotological Studies on Cervico-Aural Vertigo after Whiplash Injury; with Reference to the Theory of the Neck Reflex.

Sonoji Hine, Manabi Hinoki and Satoshi Koike.

*徳島大学医学部耳鼻咽喉科学教室 (主任: 桧学教授)

水德島県立巾央病院耳鼻呗喉科 


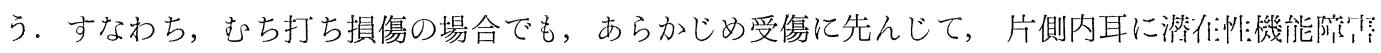

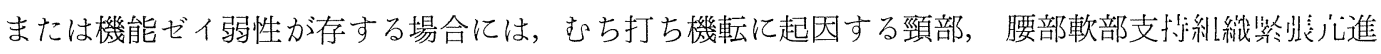
に誘発されて，耳性「めまい」，平衡失調が優位に出現する可能性があるとの仮定が成り立つ．との 論文では，以上の仮定が成立するか否かを，主として臨床成績に基づいて検討を加えてみたい。

\section{II 成}

（1）検査の対象亡なつたむち打ち損傷例： 観察の対象については表 1 亿その詳細が示さ れている。乙れらの症例はむち打ち機転を受け ているが，頭蓋に直接強力な打撲をうけた自覚 はない，受傷時一過性にボーッとしたという自 覚をもつものはいるが，頭部外傷例でみるよう

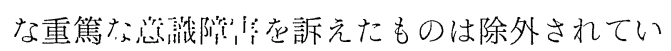
る. 検查と受傷の時期との関係は, 最短は受傷 1 時間以内より最長は 5 年以上に及んでいる が, 過半数は約 3 力月である. 被検者の年令は 16才より70才までであり，その多くが20〜30才 代である. また男子は 95 例, 女子は 41 例, 計 136 例である。

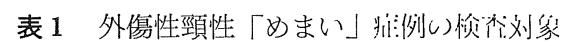
一むち打ち損傷 136 例における分析一

\begin{tabular}{|c|c|c|c|c|}
\hline \multirow{6}{*}{$\begin{array}{l}\text { 受 } \\
\text { 傷 } \\
\text { よ } \\
\text { b } \\
\text { 検 } \\
\text { 查 } \\
\text { ま } \\
\text { で } \\
\text { の } \\
\text { 期 } \\
\text { 間 }\end{array}$} & 1 ケ月まで & 45 & \multirow{2}{*}{$\begin{array}{c}91 \\
(66.9 \%)\end{array}$} & \multirow{14}{*}{136} \\
\hline & 1 ケ月以上 3 ケ月まで & 46 & & \\
\hline & 3 ケ月以上 6 ケ月まで & & 18 & \\
\hline & 6 ケ月以上 1 年まで & & 17 & \\
\hline & 1 年以上 2 年まで & & 5 & \\
\hline & 2 年以上 & & 5 & \\
\hline \multirow{3}{*}{ 年 } & $0 \sim 19$ & \multicolumn{2}{|r|}{9} & \\
\hline & $20 \sim 29$ & 46 & 93 & \\
\hline & $30 \sim 39$ & 47 & $(68.4 \%)$ & \\
\hline \multirow{3}{*}{ 令 } & $40 \sim 49$ & & 25 & \\
\hline & $50 \sim 59$ & & 7 & \\
\hline & $60 \sim$ & & 2 & \\
\hline \multirow{2}{*}{ 性 } & 子 & & 95 & \\
\hline & 文 于 & & 41 & \\
\hline
\end{tabular}

\section{績}

\section{（2）用いた検查法:}

1 ) 平衡機能検查; 立直り反射検査（両脚直

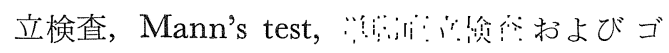
ニオメータ一検査を主として用いているが，症 例によっては加速度計を用い, 頭部動摇の加速 度記録図を作製した。)，特発および頭位眼振 検査（症例によっては頭位変換眼振検査を加え た.），上肢，下肢偏奇検査（遮眼書字法およ び足踏検查法), 実験的迷路服振椧介 (バラニー 法による回転後眼振検査わよび冷温交互試験), 眼運動系機能検査（視運動性眼振検査および視

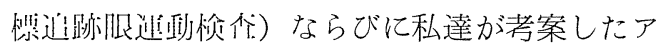
ドレナリン負荷による平衡試験（指標とする検 査としては遮眼書字法を主として採用し, 症例 によっては視標追跡運動検査を指標とした。)は いずれの症例にも施行してある.とくにての報 告では, 莖蔀惔蔀文持組織緊張元進がむち打ち 損傷の「めまい」とどのような関係を有するか を明らかにする必要があるので, 項部低周波刺 激による平衡試験を行なっている(桧ら 1967)。

2 ) 聴力検査; 純音オージオメータ一検査, recruitment 現象の検査 (Békésy オージオメ トリー, SISI test）はルーチンの検査として採

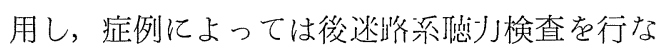
っている.

3) $\because \cdots \cdots \cdots \cdot \cdots+\cdots$ 主として行なっているが，症例によっては脳波 検査や脳血管写を行なったものもある.

この論文では, 以上の検査のうち, 必要な項 目についてのみその都度论边を進めて行くこと とする。

\section{（3）得られた成績：}

1) 問診, とくに「めまい」についての問診 成績；「めまい」についての問診を詳細にとる 
と，被検者：………自己回転感，フラフ ラ感，転倒感，眼前暗黒感およびてれらの幾つ かが組合わさったものなど，多種多様な「めま い」感を訴える。この論文では整理の便宜上, てれを回転性「めまい」（純回転感またはそれ を優位に訴えるものをてれに該当させる）と非 回転性「めまい」（回転感以外の「めまい」感 を訴えるかまたはてれを優位に訴えるものをて れに該当させる）に二大別すると，表 2 亿示し たような成績が得られる，ての成績は既に教室 からたびたび報告された成績と大略一致する （桧 1969）。すなわち，今回調査したむち打ち 損㑑例でも非回転性「めまい」を訴えるものが 多く，回転性「めまい」を示すものは少ない. 次に上述の「めまい」感とその他の問診所見,

表 2 外傷性頸性「めまい」症例における「めま い」の性格

一さち打ち損傷 136 例における分析一

\begin{tabular}{|c|c|c|c|c|}
\hline 種 & 頻 度 & 例 & 数 & $\begin{array}{c}\text { 百分率 } \\
(\%)\end{array}$ \\
\hline \multirow{3}{*}{$\begin{array}{l}\text { 回 } \\
\text { 転 } \\
\text { 性 }\end{array}$} & 湖开问幅昰 & 18 & \multirow{3}{*}{33} & \multirow{3}{*}{24.3} \\
\hline & 自己回転感 & 13 & & \\
\hline & $\begin{array}{l}\text { 周囲回転感 } \\
+ \\
\text { 自己回転感 }\end{array}$ & 2 & & \\
\hline \multicolumn{2}{|c|}{ 非 回 転 性 } & \multicolumn{2}{|c|}{103} & 75.7 \\
\hline
\end{tabular}

とくに蝸牛症状がぞのように相関するかを調 査してみると，表 3 の成績が得られた。 との 表より回転性「めまい」を訴える例では, 非回 転性「めまい」を訴える例に比し，蝸牛症状を ともなうことが多いことが判る。また，乙の表 には聴力検査成績を併記してあるが，いずれの 「めまい」例でも感音系またはての要素をふく む難聴が多いが，回転性「めまい」例では, 非 回転性「めまい」例に比し, 補充現象陽性を示 すととがより多いととが注目される。乙れらの 成績は，我々がむち打ち損傷例の問診にあたっ て, 回転性「めまい」を訴え, かつ蝸牛症状を 随伴するものを見出す場合には, 内耳障害を優 位に示すかまたはてれをともなっているものが かなりの数に存することを推定してよいてとを

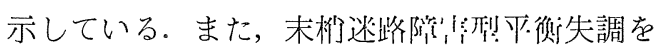
ともなう例が, 私達のむち打ち損傷例でどの程 度に出現するかを推定する目的で, 冷温交互試 験を行なってみた。その成績を整理したものが 表 4 である. 表示するように, 回転性「めま い」を有する例では, 非回転性「めまい」を示 したものに比し，GP 型または混合型を示すと とが多いととが判る，ての成績も上述した聴力 検査成績と矛盾はしない。 すなわち，聴力検

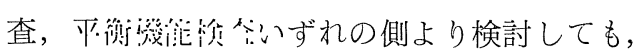
むち打ち損傷例の中に，末枌迷路䧑、に江来す る「めまい」が存するととを想定してよいと思

表 3 外傷性頸性「めまい」症例の蝸牛症状と聴力検查成績 一むち打ち損傷 136 例における分析一

\begin{tabular}{|c|c|c|c|c|c|c|c|c|c|}
\hline & & \multicolumn{4}{|c|}{ 蝸 牛 症 状 } & \multicolumn{4}{|c|}{ 聴 力検 査 成 績 } \\
\hline & & \multirow{2}{*}{ 難㯖 } & \multirow{2}{*}{$\begin{array}{c}\text { 難聴 } \\
+ \\
+ \\
\text { 耳鳴 }\end{array}$} & \multirow{2}{*}{ 耳鳴 } & \multirow{2}{*}{ 計 } & \multicolumn{2}{|c|}{ 感音性又は混合性難聴 } & \multirow{2}{*}{ 伝音性難聴 } & \multirow{2}{*}{ 計 } \\
\hline & & & & & & 補充現象 $(+)$ & |補充現象 (一) & & \\
\hline \multirow{2}{*}{$\begin{array}{l}\text { め } \\
ま\end{array}$} & \multirow{2}{*}{$\begin{array}{c}\text { 回転性 } \\
33\end{array}$} & \multirow{2}{*}{3} & \multirow{2}{*}{7} & \multirow{2}{*}{8} & \multirow{2}{*}{$\begin{array}{c}18 \\
(54.5 \%)\end{array}$} & $\begin{array}{c}10 \\
(71.4 \%)\end{array}$ & 4 & \multirow{2}{*}{2} & \multirow{2}{*}{$\begin{array}{c}16 \\
(48.5 \%)\end{array}$} \\
\hline & & & & & & \multicolumn{2}{|c|}{14} & & \\
\hline \multirow[t]{2}{*}{ い } & \multirow{2}{*}{$\begin{array}{c}\text { 非回転性 } \\
103\end{array}$} & \multirow[t]{2}{*}{10} & \multirow[t]{2}{*}{9} & \multirow[t]{2}{*}{15} & \multirow{2}{*}{$\begin{array}{c}34 \\
(33.0 \%)\end{array}$} & $\begin{array}{c}8 \\
(33.3 \%)\end{array}$ & 16 & \multirow[t]{2}{*}{5} & \multirow{2}{*}{$\begin{array}{c}29 \\
(28.2 \%)\end{array}$} \\
\hline & & & & & & \multicolumn{2}{|c|}{24} & & \\
\hline
\end{tabular}


表 4 外傷性頸性「めまい」症例の温度眼振恰查 成績

一むち打ち損傷 136 例における分析一

\begin{tabular}{|c|c|c|c|c|c|}
\hline & \multicolumn{4}{|c|}{$\begin{array}{c}\text { 温 度 眼振 検查成 績 } \\
\text { (冷温交試験) }\end{array}$} \\
\hline & & \multicolumn{4}{|c|}{ C P 型 $\mathrm{D}$ P + C P 型 D P 型|左右差なし } \\
\hline \multirow{4}{*}{$\begin{array}{l}\text { め } \\
\text { ま } \\
\text { ( }\end{array}$} & \multirow{2}{*}{$\begin{array}{c}\text { 回転性: } \\
33\end{array}$} & 12 & 11 & \multirow{2}{*}{3} & \multirow{2}{*}{7} \\
\hline & & \multicolumn{2}{|c|}{$23(69.7 \%)$} & & \\
\hline & 非回転性 & 10 & 13 & \multirow{2}{*}{29} & \multirow{2}{*}{51} \\
\hline & 103 & \multicolumn{2}{|c|}{$23(22.3 \%)$} & & \\
\hline
\end{tabular}

う。ただし上述したように，回転性「めまい」 そのものがむち打ち損傷例では多発していな い，従って全体の症例汃みると，耳性「めま い」を優位に呈するものは高頻度に存するもの ではない。

\section{2 ) 平衡機能検查成績からみたむち打ち損傷} の「めまい」症例，とくに末梢迷路障害型「め まい」症例に関する成績；以上述べたように， 回転性「めまい」を示すものの中には，温度眼 振検査で $\mathrm{GP}$ 型または混合型を呈し，また聴力 検査で recruitment 現象が陽性所見を示すも のが存する。しかし，ての成績のみをもって直 ちにこれらの例の「めまい」が，純粋にまたは 優位に末梢迷路（とくに内耳）障察型市衡人洞 に基づくものであるか否かを推定できない。そ
れにはその他の詳細な検査を併用し決定する必 要がある. とくに，劣ち打ち損傷か泇わる場合 は, ある特定の器官が単独に障害され，それに もとづいて「めまい」が出現するとは考えがた い. 従って, 実状としては，障害された器官の うちある特定の器官の障害が優位であり，それ にもとづく「めまい」が優勢に出現していると 考えるべきであろう．以下，先ず代表例をあげ てての問題を説明し, 次いで私達がとりあつか った 136 症例においての成績を申し述べたい。

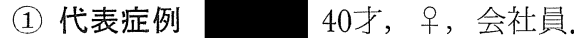

主訴：回転性「め末い」, 左耳冩, 左側項部 痛と頭痛.

現病歴：9 力月前自転車で通行中，追突され た．事故直後より左側項部痛，同側の頭痛およ び左側耳鳴があり，整形外科で治療をうけてい る. 現在のところ，八侧项湮疗と頭痛は軽減し ている. しかし，事故後 1 力月目位より，1日 2 回位の割合でおこる発作性回転性「めまい」 を経験している．乙の際，同時に左側耳鳴が増 強し，樞気をともなうという。乙の症状は，治 療により一旦消失していたが，最近再び発現す るようになっている。なお，「めまい」発作は 疲労などに際して左肩てりか強くなると誘発さ れやすいという。

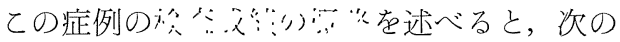
通りである。すなわち表 5 に示したように，立

表 5 主要検查 成 績

一回転性「めまい」を訴えた症例における観察一。

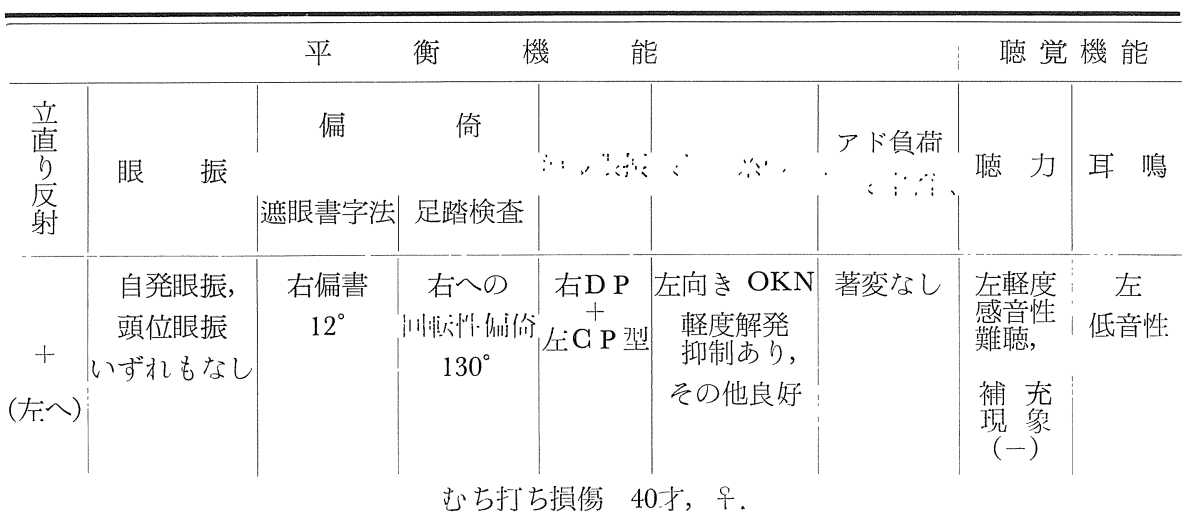


直り反射検查では軽度の左への転倒傾向がうか がわれる．特発ならびに頭位眼振検査ではいず れも異常を認めない，遮眼書字法を行なうと，

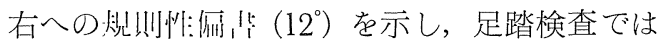
右への检悱作份（回転角 $130^{\circ}$ ）が出現してい る. 回転後眼振検查（バラニ一法）では，右回 し，左回しともに正常值を示し，左右差はな い. 温度眼振検査では右 DP + 左 CP の混合型 である. 視標追跡眼運動検査は正常であった が，視運動性眼振検査では，左向きの視運動性 眼振に軽度の眼振解発抑制が見られた.アドレ ナリン負荷による平衡試験を遮眼書字法を用い て行なうと，遥眼文字に有意の変動を認めてい ない。なお聴力検査では補充現象は陰性であっ たが，左側に 軽度の感音性難聴の像がみられ た。この例は左向き視運動性眼振に軽微ながら

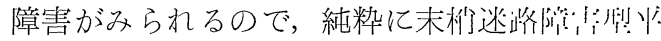
衡失調に終始するものとはいえない.しかし， 上述の検査成績の多くは，本例の「めまい」が 左側末梢迷路機能障害に由来して成立している ことを示唆している。もちろん， recruitment 現象が陰性であるので，乙の「めまい」が内耳 障害に由来するものかまたは第 8 神経の障害に 由来するものかは即断はできない。しかし，て れまでの動物を用いた実験成績より案ずるなら (三浦ら 1970)，その主病巣を左側第 8 神経に 求めるよりは，左側内耳に求める方が妥当と考 える。なお，乙の例では項部痛と「めまい」に

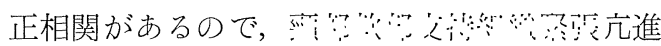
がこの例の「めまい」発現に一役を果している ことと考えられる。この問題については後述し たい.

要するにとの例のように，むち打ち機転を受 けた後に「めまい」を来し，それが末梢迷路， とくに内耳の障害による「めまい」と考えてよ い症例が存するととは事実である.

(2) 136 例の 観察から 得た内耳障害型「めま い」症例の成績：上述したように調查した 136

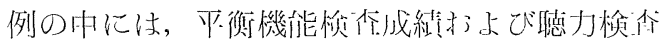
成績よりみて，内耳障害在合作する「めまい」
例が存するととは肯定してよい，例えば，温度 眼振検査で CP 型または混合型を示すものは 136 例中 46 例， $33.8 \%$ （表 4 参照）ある。また 聴力検査で recruitment 現象を呈する「めま い」例は 136例中 18例， $13.2 \%$ (表 3 参照) で ある. しかし，同時にその他の平衡機能検査，

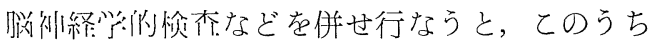

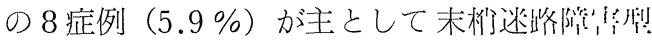
「めまい」例と理解できる，表 6 亿は各々の成 績の大略を示してある。

\section{3 ）むち打ち損傷例の末梢迷路障害型「めま} い」と頸部軟部支持組織緊張え進の相関 ;

i ) 問診で得られた成績からみた両者の相

関：屯ち打ち損傷例で回転性「めまい」を訴え るものと非回転性「めまい」を訴えるもので

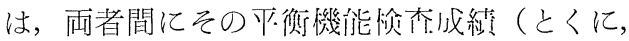
温度眼振検查) や聴力検查. 成績（とくに，recruitment 現象) が相当度の相違を示す。さて 桧らは，むち打ち損傷でみられる「めまい」 は，項部痛と正相関するととが多く，後者の症 状は前者の症状発現の「引き金」的役割を果す ものと指摘している。しかし，桧らがタた症例 の多くは，非回転性「めまい」を訴える例であ り，またその多くは中怄则経陮、刑平衡失調を

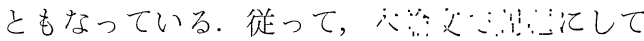
いる内耳障害型平衡失調が，それと類似の機序 で成立するかどうかはなお研究の余地が多い。 この問題究明の手はじめに，ここで「めまい」 と項部痛の相関を改めてとりあげてみたい，表 7 亿は，136 例を回転性「めまい」を訴えた群 と非回転性「めまい」在訴えた群に分け，それ ぞれの「めまい」と項部痛の相関を観察してみ た，表示するように，回転性「めまい」群，非 回転性「めまい」群，いずれの場合にも「めま

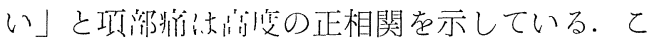
の事実は，むち打ち損傷における内耳障害型

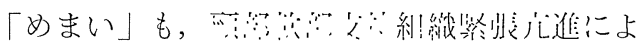
り誘発されるととを物語っており，示唆にと 㤂。

ii）項部低周波刺激の成績からみた両者の相 


\begin{tabular}{|c|c|c|c|c|c|c|c|}
\hline 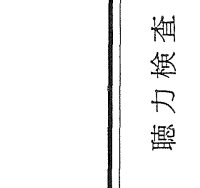 & 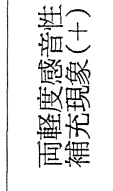 & 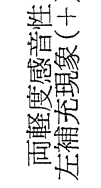 & 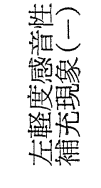 & 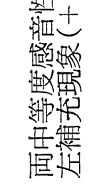 & 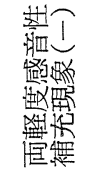 & 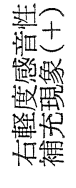 & 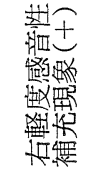 \\
\hline 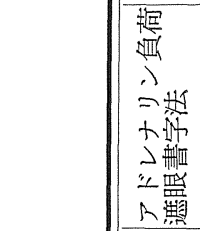 & 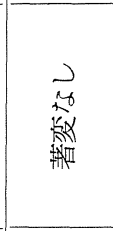 & 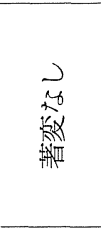 & 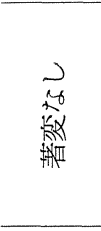 & 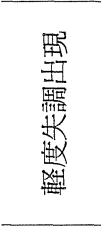 & 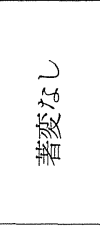 & 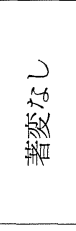 & 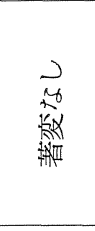 \\
\hline 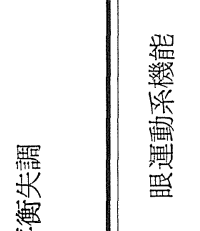 & 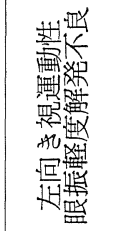 & 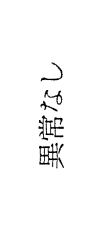 & 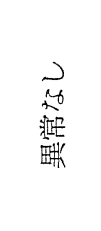 & 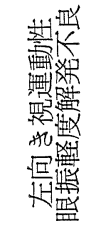 & 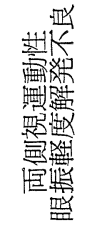 & 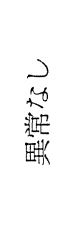 & 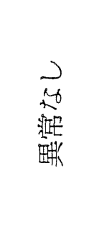 \\
\hline 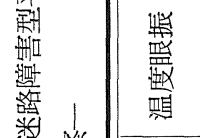 & $\begin{array}{l}n \\
\theta \\
H+U \\
H\end{array}$ & $\begin{array}{l}0 \\
0 \\
H\end{array}$ & $\begin{array}{l}0 \\
0 \\
H\end{array}$ & $\begin{array}{l}0 \\
0 \\
H\end{array}$ & $\begin{array}{l}0 \\
0 \\
i\end{array}$ & $\begin{array}{l}0 \\
0 \\
+I I\end{array}$ & 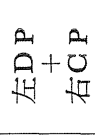 \\
\hline 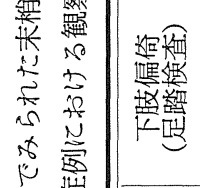 & 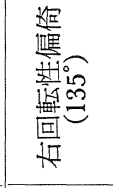 & 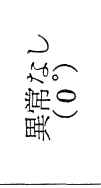 & 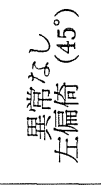 & 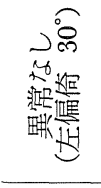 & 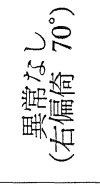 & 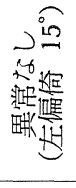 & 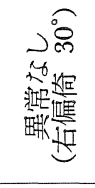 \\
\hline 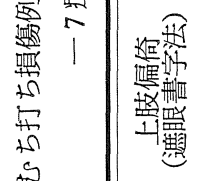 & 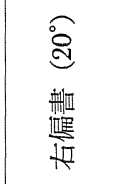 & 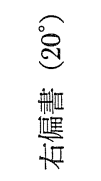 & 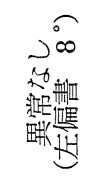 & 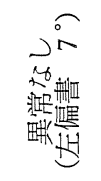 & 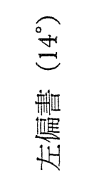 & 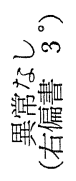 & 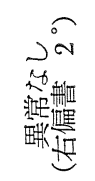 \\
\hline 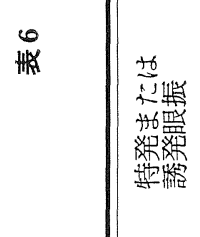 & 30 & 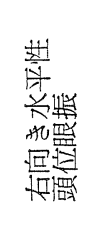 & $0^{6}$ & 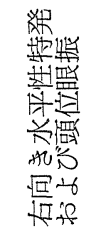 & 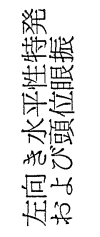 & 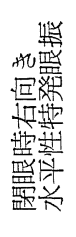 & 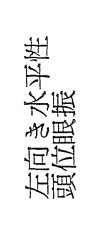 \\
\hline 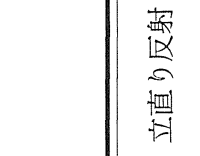 & 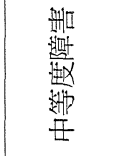 & 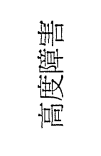 & 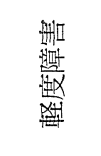 & 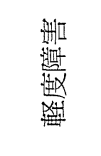 & 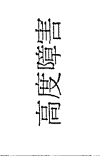 & 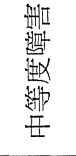 & 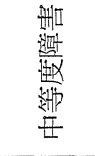 \\
\hline 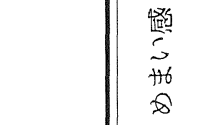 & 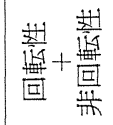 & 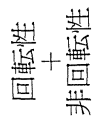 & 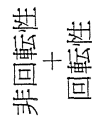 & 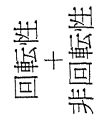 & 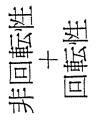 & 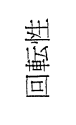 & 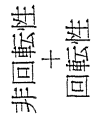 \\
\hline & 号 & $\begin{array}{l}m \\
\dot{z}\end{array}$ & $\begin{array}{l}+H \\
\dot{\alpha}\end{array}$ & $\begin{array}{l}10 \\
\dot{8}\end{array}$ & $\begin{array}{l}0 \\
\dot{8} \\
\dot{2}\end{array}$ & ì & $\begin{array}{l}\infty \\
\dot{\delta} \\
\dot{z}\end{array}$ \\
\hline
\end{tabular}


表 7 外傷性頸性「めまい」の相関症例における 項部痛の有無と「めまい」

一むち打ち損傷 136 例における分析一

\begin{tabular}{|c|c|c|c|}
\hline & 項 & 痛 \\
\hline & & $(+)$ & $(-)$ \\
\hline \multirow{2}{*}{$\begin{array}{l}\bigotimes \\
ま \\
\omega\end{array}$} & $\begin{array}{c}\text { 回転性 } \\
33\end{array}$ & $\begin{array}{c}30 \\
(90.9 \%)\end{array}$ & 3 \\
\hline & $\begin{array}{c}\text { 非回転性 } \\
103\end{array}$ & $\begin{array}{c}88 \\
(85.4 \%)\end{array}$ & 15 \\
\hline
\end{tabular}

関 : 私達は上述の項目であげた 8 症例は, 主と して内耳障害に由来して「めまい」, 平衡失調 が成立しているものと考えている，てれらの例 はいずれも項部痛を有している，従って，問診

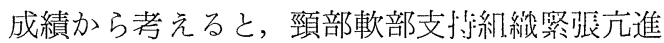
を一つの「引き金」としててれらの症例の「め まい」が成立しているととを想定してよい。乙 の考光が事実か否かを先ず代表例をあげて検討 し，ついでその他の 7 症例でえた成績について 考察してみたい.

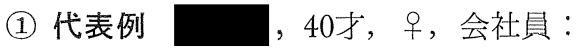

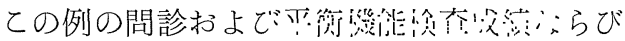
に聴力検查成績については上述してある。との 例の頸部軟部支持組織緊張亢進が「めまい」発 現の「引き金」的役割を果しているか否かを明 がするため，項部低周波刺激による桨衡武験 を行なってみた。その成績を以下紹介したい。

\section{低周波刺激前}

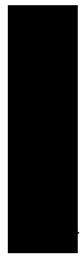

项蔀低们波制激を加えると，ての例では回転 感か増大したと訴えている。乙の際の平衡機能 検査の変動は次の通りである.すなわち図 1 に 示したように, 特発眼振検査では, 低周波刺激 前に明瞭な眼振をみとめていない。しかし，低 周波刺激を加えると，下段に示すように，左向 き水平性眼振力゙明瞭に出現している. また図 2

\section{低周波刺激前}

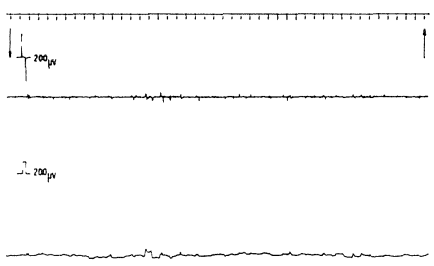

左低周波刺激：10分
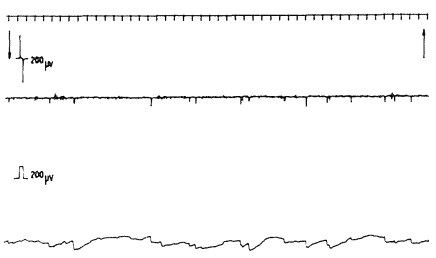

むち打古损傷 $40 x$ ，早。

図 1 項部低周波刺激による特発眼振（または眼 運動）の変動

左低周波刺激：10余
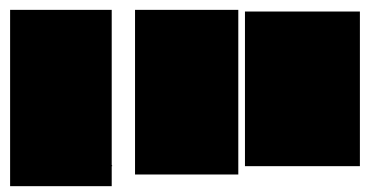

\section{むち打掑㑥 40未, 早。}




\section{低周波刺激前}

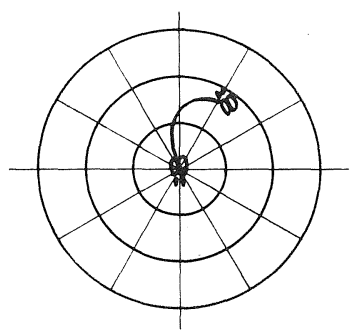

左低周波刺激：10分

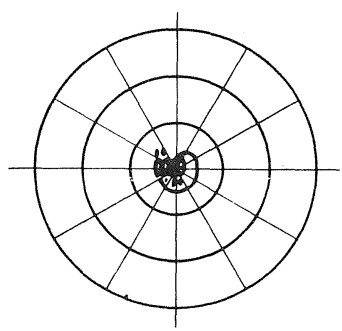

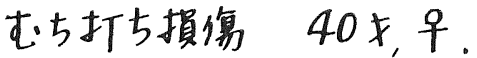

図 3 項部低埖波刺激による足踏偏倚の変動

\section{低周波刺激前}

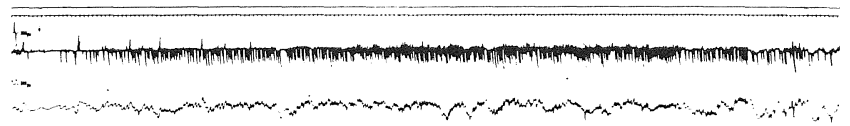

左低周波刺激：10分

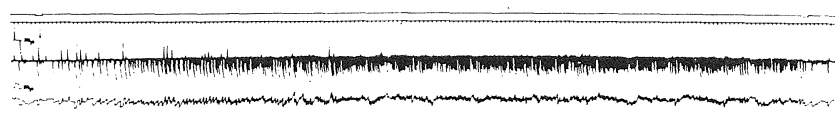

むち打占損傷 40 ォ, 古。

図 4 項部低周波刺激による視運動性眼振の变動（円筒右回し：1.0 $/ \mathrm{sec}^{2}$ )

に示した如く, 同じ操作で, 右偏書の規則的増 大 $\left(12^{\circ} \rightarrow 28^{\circ}\right)$ がみられた. さらに図 3 亿示し た如く，項部低周波刺激で，失調をともなわな い右向き回転性偏奇の増大 $\left(130^{\circ} \rightarrow 300^{\circ}\right)$ がみ られている．また図 4 亿示したように，視運動 性眼振は低周波刺激前後において有意の変動を 見ない。

ての成績より案ずると, 本例では項部低周波 刺激前には主として左側内耳障害に由来すると 考えられる「めまい」，平衡失調が出現してい る。そして左項部（有痛側）を低周波刺激した 場合，回転感か増大し，乙れを裏付ける平衡機 能の変動がタられる。乙の際, 特発眼振, 上肢
偏奇, 下肢偏奇の変化より考えると, この操作 で頸部軟部支持組織緊張方進が抽り，てれに 由来して末梢迷路障害型平衡失調の増強がみら れたと理解すべきであろう。

(2) その他の 7 症例で得られた成績 :

項部低周波刺激前, 内耳障害型平衡失調を優 位に示すと見做された 7 症例の, 項部低周波刺 激による平衡機能の変動を表 8 亿示してある. この表に示したように，「めまい」感は７例中 4 例， $57.1 \%$ 亿出現または増強をみとめ，ての うち 3 例は回転性「めまい」の出現または增大 を訴光ている。また，立直り反射では 7 例中 3 例， $42.9 \%$ に障害の增強がみられ，特発または 
表 8 項部低周波刺激による平衡機能検査成績の変動 一未梢迷路障害型平衡失調を呈した 7 症例における観察—

\begin{tabular}{|c|c|c|c|c|c|c|}
\hline & めまい感 & 立直り反射 & $\begin{array}{l}\text { 特発または } \\
\text { 誘発眼振 }\end{array}$ & 遮眼書字法 & 足踏検查 & 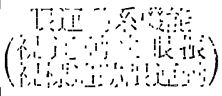 \\
\hline No. 2 & 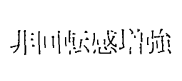 & 障嗐増強 & 変動なし & $\begin{array}{l}\text { 右偏書 } \rightarrow \text { 右偏書 } \\
\left(20^{\circ}\right) \\
\left(24^{\circ}\right)\end{array}$ & 右 $\left(135^{\circ}\right) \rightarrow$ 右 $\left(180^{\circ}\right)$ & 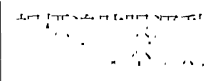 \\
\hline No. 3 & 不 変 & 不 変 & 変動なし & $\begin{array}{l}\text { 右偏畫 } \rightarrow \text { 右偏畫 } \\
\left(20^{\circ}\right)\end{array}$ & $0^{\circ} \rightarrow 0^{\circ}$ & 変動なし \\
\hline No. 4 & 回転感出現 & 障害増強 & $\begin{array}{l}\text { 右向き水平性 } \\
\text { 特発眼振出現 }\end{array}$ & $\begin{array}{l}\text { 左偏書 } \rightarrow \text { 左偏書 } \\
\left(8^{\circ}\right)\end{array}$ & 左 $\left(45^{\circ}\right) \rightarrow$ 左 $\left(45^{\circ}\right)$ & 変動なし \\
\hline No. 5 & 不 変 & 不 変 & 変動なし & $\begin{array}{l}\text { 左偏書 } \rightarrow \text { 左偏書 } \\
\left(7^{\circ}\right)\end{array}$ & 左 $\left(30^{\circ}\right) \rightarrow$ 左 $\left(45^{\circ}\right)$ & 変動なし \\
\hline No. 6 & 不 変 & 不 変 & 変動なし & $\begin{array}{l}\text { 左偏書 } \rightarrow \text { 左偏書 } \\
\left(14^{\circ}\right)\end{array}$ & 右 $\left(70^{\circ}\right) \rightarrow$ 右 $\left(90^{\circ}\right)$ & 変動なし \\
\hline No. 7 & 回転感増強 & 障害増強 & 変動なし & $\begin{array}{l}\text { 右偏書 } \rightarrow \text { 右偏書 } \\
\left(3^{\circ}\right) \quad\left(7^{\circ}\right)\end{array}$ & 左 $\left(15^{\circ}\right) \rightarrow$ 左 $\left(100^{\circ}\right)$ & 変動なし \\
\hline No. 8 & 回転感出現 & 不 変 & $\begin{array}{l}\text { 左向き水平性特発 } \\
\text { 眼振出現, 頭 位 } \\
\text { 眼振増強 }\end{array}$ & $\begin{array}{l}\text { 右偏書 } \rightarrow \text { 右偏書 } \\
\left(2^{\circ}\right)\end{array}$ & 右 $\left(30^{\circ}\right) \rightarrow$ 右 $\left(180^{\circ}\right)$ & 変動なし \\
\hline
\end{tabular}

誘発眼振検査では，低洞波刺激後 1 例力特発眼 振を出現し，他の 1 例が特発眼振を出現すると ともに，既存の頭位眼振を増強した。ただし， 両者ともに出現した眼振は水平性であり，また 後者の例で既存の眼振が増強した場合でも，そ の方向や性格の変化はなかった，遮眼書字法で は 7 例中 2 例が，低周波刺激後その偏書度を病 的に増大したが，方向の変化はなかった．また 足踏検査では 7 例中 3 例に変化をみたが，いず

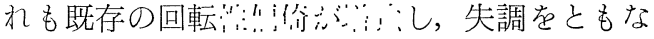
う後方への足踏偏倚などは出現しなかった。

以上を要約すると，低周波刺激前に未梢迷路

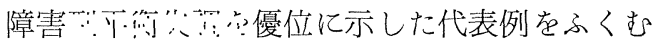
8 症例 では，低周波刺激後に「めまい」（とく に回転感）の出現または増強を訴え，かつ末梢

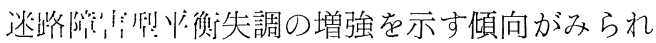
万。

\section{III 総 括と考案}

（1）むち打ち損傷で内耳性「めまい」はお こりうるか：むち打ち機転で内耳障害が正常人 においてもおてりうるかどうかは，ヒトにおい てはなお系統的に明らかにされていない。しか し三浦らは，ヒトのむち打ち損傷研究の資料を 得るためウサギを対象とし，乙れに衝撃による 頭部の加速減速度運動を強制する実験をおてな い，次の事実を明らかにしている，すなわち彼 等の報告によると，加えられる衝撃（G）が比 較的小である場合（たとえば $5 \mathrm{G} ）$ は，中枢神
経系に先ず変化がおこり，とくに脳幹より上位 頸髓にかけて集中的に形態的変化がおこるとい う。この形態的変化を，彼らは，乙れらの脳の 動静脈系，とくに静脈系に血管破綻（血管に注 入された墨汁の漏出でしれ、を検定）として客観 化している. これに対し，内耳の支配血管にこ のような所見がおこるのは $7 \mathrm{G}$ 以上の強力な衝 撃か泇わる必要があるという（三浦ら 1970）。 この実験よりすると，ヒトの場合でもむち打ち 機転で, 強力な頭部加速減速度運動が強いられ 
る場合は，内耳にも機能的変化がおこりうるこ とを肯定せ权ばならない。 そして若し，受傷に 先んじて内耳の機能にゼイ弱性が存する場合に は，乙の機転でより容易に内耳機能破綻がおて りうるととも考えられてょい，以上の成績は， ヒトの場合でもむち打ち損傷による内耳性「め まい」，平衡失調が成立するか否かを直接証明 しうるものではもちろんないが，乙の可能性を 示す示唆に富む成績と考えている. しかし，む ち打ち損傷での内耳障害型「めまい」, 平衡失 調は, 上述した私達の成績から考えても多発す るものとは思气ない，乙の考えは，協同研”兄谷

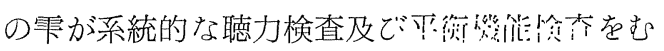
ち打ち損傷例に行なって得た結果からも肯定で

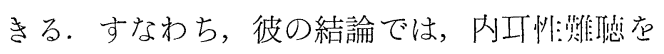
純粋に示すかまたはてれを優位に示すむち打ち 損傷例は予想されたよりはるかに少ない（雫 1973). 以上，私はての項目でむち打ち機転を

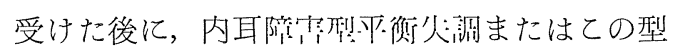
の平衡失調を優位に示す「めまい」例があるこ とを肯定したい.しかし，その頻度は中枢神経 系, 特に脳幹障害をともなって出現する「めま い」例に比し有意に少数であることを指摘した い. おそらくその理由は, 通常我々が臨床例で みる程度のむち打ち機転では生体に加わる衝撃 はさして強力でなく，従って特定の条件（たと えば受傷に先行する内耳の機能的または器質的 椇傷）がないかぎり，内耳障害が誘発されがた いことに由るものであろう。

（2）むち打ち損傷による内耳性「めまい」, 平衡失調発現における頸部軟部組織, 特にその 脊柱起立筋緊張亢進の意義: 桧らは, むち打ち 損傷による「めまい」発現の一つの機序は, 頸 部軟部支持組織, 特にその部の脊柱起立筋の緊 張亢進（すなわちその部の深部受容器の活動性 亢進）と中枢神経系, 特に脳幹, 小脳などの平 衡脳の機能が互いに「引き金」と「まと」の関 係をなし，平衡失調を悪循環的に増強し，これ にもとづいて「めまい」が形成され持続するも゙ のと考えている（桧 1971）。乙の考えは協同研
究者の石田の実験成績よりも支持されている. すなわち石田は, ウサギの片側深層項筋に比較 的強い電気刺激 $(10 \mathrm{msec}, 10 \mathrm{~Hz}$ の矩形波, 15V 90") をくりかえしあたえることにより， ウサギに特発眼振を惹起させ，同時に視運動性 眼振の抑制, 錯倒現象の成立および知覚刺激(視 運動刺激)に対する脳波の arousal 化困難など をひきおてすととに成功している(石田 1972）。 しかし，ヒトの内耳性「めまい」，惨行火测例 で，ての症状が頸部軟部支持組織の緊張元進で 誘発または増強されるか否かを明らかにしたも のはないままたそれを動物を用いて実験的に実 証したものもない. 以下，乙の問題について述 べて行きたい.

1) 上述したように，むち打ち損傷後に少数

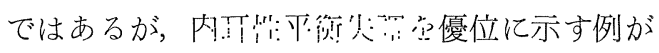
ある.またてれらの例では, 項部痛などその部 の軟部支持組織緊張穴進を示唆する愁訴を同時 にともなうことが多い。さらに，てれらの例 の項部有痛部に低周波刺激を加えると，「めま い」, とくに回転性「めまい」が増強され，末

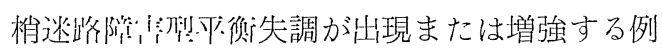
があるととが判明した，乙の事実は，内耳にあ らかじめ障害が存する場合は, 頸部軟部支持組

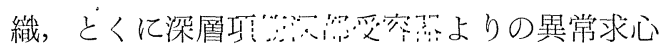

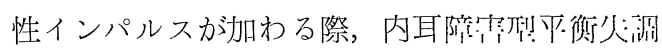
が manifest となり，てれにもとずいて「めま い」か溌現または増強されることを明らかにし ている.すなわち, むち打ち損傷による内耳障 害型「めまい」, 平衡失調の発現機序にも, 桧 らの考えは原则们に心てはまると考えてよい。

2 ）ての問題を臨床例で更に明らかにするに は，耳性「めまい」を有する非外傷性「めまい」 例で, かつ項部痛, 項部緊迫感など頸部軟部支 持組織緊張元進を示す症例をえらび，1）と同 様な操作をおてない，果して内耳障害型「めま い」，平衡失調が増強されうるかどうかを観察 してみるとよい，私達は20症例の非外傷性耳性 「めまい」例を対象とし，乙の問題を究明して みた。 
(1) 症例 2 , 32才, 오, 主婦.

主訴：回転性「めまい」発作。

現病歴：約 6 力月前回転性「めまい」発作を 来す. その発作は 3〜 4 日間持続し, 消失し た.しかし 2 力月前後の休止期を経て再び「め まい」発作がおこり，乙れまでに 3 回その発作 をみている。「めまい」発作に際しては嘔気を

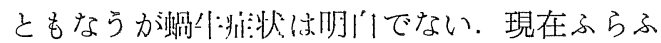
ら感を主とする非回転性「めまい」を残すとと もにハ项㰾緊迎感，肩こりおよび頭重感を訴え ている。なお疲労が重なると項部緊迫感は項部 痛となり，との際ふらふら感は回転性「めま い」要素を強めるという。

この例では，左への軽度転倒傾向 があり，

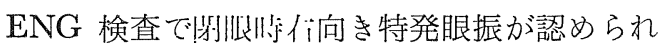
る (因 5 参照). この眼振は暗算負荷により増 強を示した，上肢偏倚検查，下肢偏倚検査で異 常はない，温度眼振検査は右 CP 型である. 眼 迎䣦系機能俭惁は正常であり，アドレナリン負 荷による平衡試験も異常がない，従って，この 例は右末梢迷路に病栄を有する耳性「めまい」 例と見做してよい，乙の症例の項部有痛側（左 側）飞低周波刺激を10分間加えると，ふらふら 感は回転性「めまい」となった。この際 ENG 記録を行なうと，図 5 の下段に示した如く，右

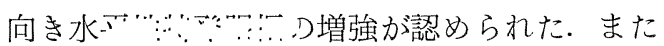
図 6 亿示した如く, 同じ操作で, 左偏書の増大
低周波刺激前

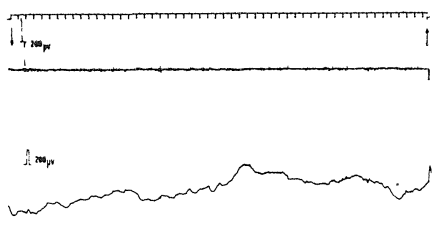

左低周波刺激：10分

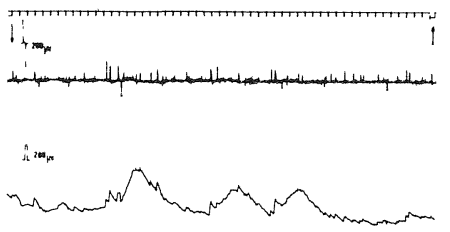

耳性りまい」32も, 古。

図 5 項部低周波刺激による特発眼振（または眼 運動）の変動

がみられたが失調文字などの出現はない。ただ し図 7 に図示した如く，低周波刺激を行なって も， $: \cdots \cdots \cdots$ れていない，乙の検査成績より，低周波刺激に

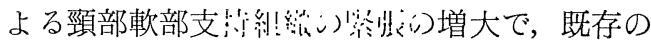

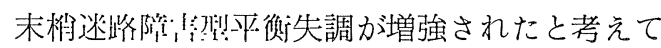
よい.そしてふらふら感が回転性「めまい」と

\section{低周波刺激前}

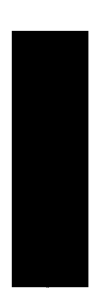

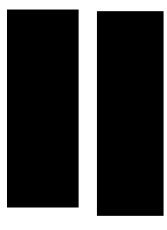

左低周波刺激：10分

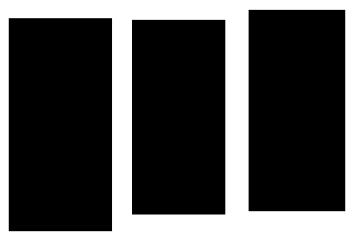

\section{耳性「めま」32ォ, 早。}

图 6 項部低周波刺激による遮眼文字の変動 


\section{低周波刺激前}

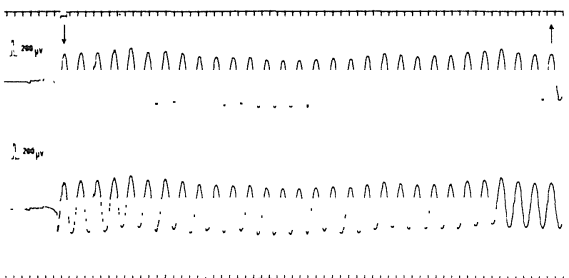

\section{左低周波刺激：10分}

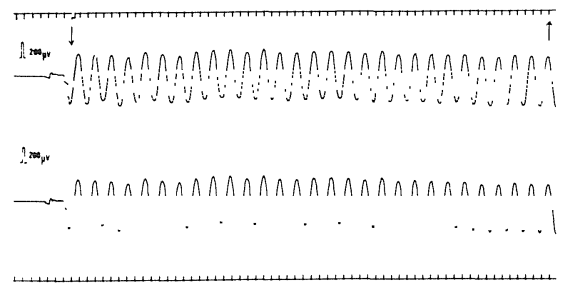

\section{耳性「まい,32丈，早。}

図 7 項部低周波刺激による視標追跡腿運動軌跡 の变動

なったととも，以上のように解釈すると納得が 行く、ちなみに本例は, その後の経過中に回転 性「めまい」の小発作を起したが，その際項部 有痛部 procainization を試みた所，恩時閒な がら「めまい」感の軽減を覚えるとともに，有 向き特発眼振の抑制か認められた。とのような 事実も，頸筋緊張圥進と本症例の「めまい」が 密接な相関を有するととを物語り，上述の結論 と矛盾しない.

以上の代表例をもふくめて20症例の非外傷性
耳性「めまい」例の観察結果の概略を示すと表 9 のようになる。すなわち, 項部低周波刺激で 「めまい」感が出現または増強をみたものは 20 例中 8 例，40\%であるが，乙のうち回転性「め まい」が誘発されるか, 既存の回転性「めま い」が増強されるか，あるいは非回転性「めま い」が回転性「めまい」へと変化したものは計 5 例ある。 さてい最も高率に平 衡機能の変動（増覀）を示す検查項目は，立直 り反射検查である（20 例中 8 例， $40 \%$ )。特発 または誘発眼振検查の項目で20例中 7 例に变動 をみている，すなわち，特発眼振の出現または 增強をみたもの 4 例， $20 \%$ ，特発眼振とともに 頭位眼振の増強をみたたもの 3 例，15\% であ る．ただし眼振が消失したものや，既存の眼振 がその性格を変化したものはない，遮眼書字法 では，20例中 4 例飞変化がみられたが， 3 例は 同じ方向への規則正しい偏書の増大を示し， 1 例は偏書方向の逆転をみている，ただしいずれ の場合にも，失調文字の出現はない，また足踏 検查では，20例中 5 例に変化がみられている.

これは既存の足踏偏倚が增強された形をとった もの 4 例，偏倚方向逆転をみたもの1例であ る。ただし出現した下肢偏倚はいずれも回転性 偏倚であり，足踏失調の出現や後方への足踏偏 倚などはなかったななお，眼運動系 機能検查

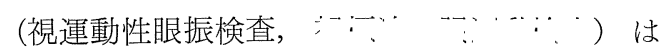
項部低周波刺激前後, いずれも正常で, 有意の 変動をみていない.すなわちてれら20症例の非

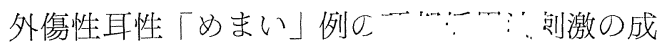

表 9 項部低周波刺激による平衡機能の変動

一項部痛をともなう耳性「めまい」20症例における観察—

\begin{tabular}{|c|c|c|c|c|c|}
\hline & \multirow{3}{*}{ 立直り反射 } & 平 & 衡 & 能 & \multirow{3}{*}{ 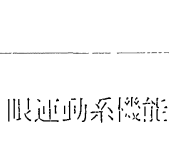 } \\
\hline & & 特発または & \multicolumn{2}{|c|}{ 偏 倚 検 查 } & \\
\hline & & ないし増強 & 遮眼書字法 & 足踏検查 & \\
\hline 变㓰（十） & 8 & 7 & 4 & 5 & 0 \\
\hline 変 動（一） & 12 & 13 & 16 & 15 & 20 \\
\hline
\end{tabular}

20例中 8 例，40\%に「めまい」感の一過性増強あり，うち5 例は回転感を自覚与。 
績より案ずると，高頻度ではないが，ての操作 で「めまい」，平遇人洞が誘発または増強する 場合は，内耳性「めまい」，平衡失調が出現ま たは増強の形をとることが判明した，従来，非

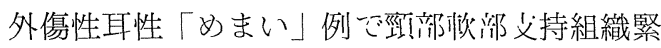
張元進が，この種「めまい」，平衡失調を惹起 または増強する事実は充分に証明をうけていな い.この点で上述の成績は貴重である．またて の成績は，上述したむち打ち損傷例で末梢迷路

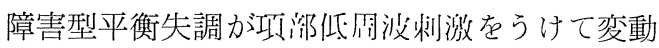
する場合は，同じ型の平衡失調が出現または増 強する事実と対応している，従って，以上の所 見は，“むち打ち損傷による耳性「めまい」発 現に際して, 頸部軟部支持組織緊張穴進は「引 き金」的役割を果す”との考えに更に新しい証 拠を与えており貴重である。

3）以上の臨床所見をなお一層裹付け，上述 した考えの妥当性を確立するには，動物を対象 とする観察もその一方法と思う，乙のため，片 側末柎迷路に㙨俄们損傷をあたえ, 特発眼振を 来すようになったウサギで，その眼振が消失ま

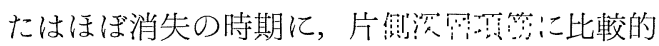
強い電気刺激 $(10 \mathrm{msec}, 10 \mathrm{~Hz}$ の矩形波, $15 \mathrm{~V}$ $90^{\prime \prime}$ ) 加え，潜在性の迷路性特発眠振 が頸筋 緊張の増大でどのような態度を示すかを観察し た。すなわちこの実騟の目的とするとてろは， 受傷に先行して内耳に損傷を有するかまたは機 能的ゼイ弱性が存する場合, 䣆伤篹侲充進は内 耳性「めまい」，平衡失調を優位にひきおこし うるかどうかを決定するととにある，以下，得 られた成績について申し述べてみたい。

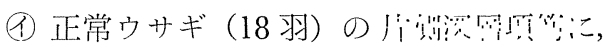
上述の電気刺激を加えても, 明らかな眼振を出 現しなかった。乙の成績は協同研究者の石田が 報告した同様の実験成績と原則的に一致する (石田 1972).

(口)片側末梢迷路を機械的に障害し，その特 発眼振が消失またはほぼ消失した状態にあるウ サギの深層項筋に，同様の電気刺激が加えられ る場合はその多くに，次に例示する現象がおて
った.

ウサギ No. 13 : このウサギは左側末梢迷路 亿機械的損傷をあたえた。 その結果, 術後 3 日 目までは右向き水平性眼振が出現していた. 3 日目より次第に眼振の出現頻度を減じ，5日目

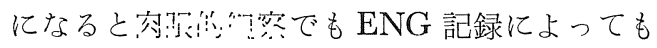
眼振は認めがたくなっている.さて術後 6 日目 に左側深層項筋に上述の電気刺激を加えると,

図 8 亿示したように，右向き（健側）水平性眼 振が明膫に出現してくる. この眼振は, このウ

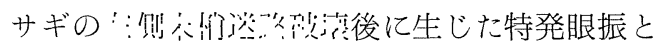
相似している。ちなみに，てのウサギの同じ筋 に比較的弱い電気刺激 $(10 \mathrm{msec}, 10 \mathrm{~Hz}$ の矩形 波, IV 90") を加えたが，眼振は出現しなかっ た.

以上のウサギをもふくめて，片側末梢迷路損

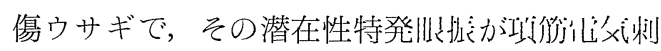
激の結果誘発されたのは，18羽中10羽，55.6\% である．表10，表11亿は，その各々の成績を総 括的に表示してある. 表示するように，眼振は いずれも水平性であるが，健側（右側）向きの 眼振が誘発されたものはこのうち7羽であり, 手術側（左側）向き眼振が誘発されたものは 3 羽である. また，左または右項筋いずれの項筋 の電気刺激によっても腿振か誘発されたものは 2 羽であり, 他の 8 羽はいずれか一方の項筋の 電気刺激で眼振が出現している（在侧项伤の電 気刺激をしなかった 1 羽のそれをふくむ)。た だし以上の 2 羽で右または左項筋の電気刺激が 異なった方向への水平性眼振を誘発したものは ない，また，1:侧项筋の電気刺激で腿振の誘発 をみたものは 6 羽, 右側のそれで眼振の誘発さ れたものも 6 羽であり，眼振誘発に対していず れの項筋の六舊性増大がより優位であるかは， ての実験に関するかぎり明白ではなかった。す でに, 協同研究者の福井は片側迷路障害ウサギ の深网项竹存 procainization し, 手術に際し

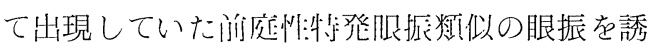
発するととに成功している，そして手術後日の 浅い場合は，健側向きの水平性眼振が，また手 


\section{刺激前}

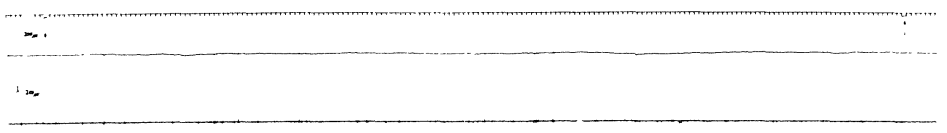

\section{刺激後}

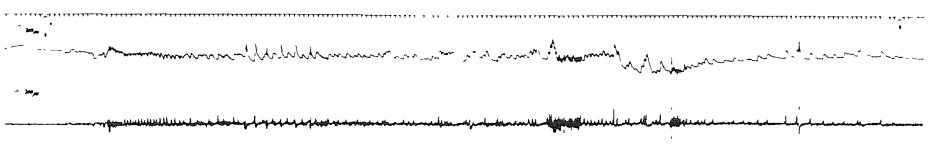

図 8 深層項筋電気刺激で誘発される眼振, 眼運動

左側末梢迷路破䏅後 6 日目のウサギでは，15V,90”の電気刺激によって右側 迷路向き水平性特発眼振が活発に誘発されてきている.

表10 15V90" の深首項份電気刺激による前庭性特発腿宸の变動

\begin{tabular}{|c|c|c|c|}
\hline \multirow{2}{*}{$\left.\begin{array}{c}\text { 動 物 } \\
\text { (左側末梢 } \\
\text { 迷路破壊 }\end{array}\right)$} & \multirow{2}{*}{ 刺激側 } & \multicolumn{2}{|c|}{ 前 庭 性 特 発 眼 振 } \\
\hline & & 刺 激 前 & 刺 激 後 \\
\hline No. 1 & $\begin{array}{l}\text { 左 側 } \\
\text { 在 側 }\end{array}$ & $\begin{array}{l}( \pm) \\
\text { 刺 激 }\end{array}$ & $\begin{array}{l}\text { 右向き，振巾小，小頻度 } \\
\text { せ ず }\end{array}$ \\
\hline No. 2 & $\begin{array}{l}\text { 左 側 } \\
\text { 右 側 }\end{array}$ & $\begin{array}{l}(-) \\
( \pm)\end{array}$ & $\begin{array}{c}(-) \\
\text { 左向き，振门中等度，きわめて高頻度 }\end{array}$ \\
\hline No. 3 & $\begin{array}{l}\text { 左 側 } \\
\text { 右 側 }\end{array}$ & $\begin{array}{l}( \pm) \\
( \pm)\end{array}$ & $\begin{array}{l}( \pm) \\
( \pm)\end{array}$ \\
\hline No. 4 & $\begin{array}{l}\text { 左 側 } \\
\text { 右 側 }\end{array}$ & $\begin{array}{l}(-) \\
(-)\end{array}$ & $\begin{array}{c}\text { (一) } \\
\text { 左向き，振巾小または大，小頻度 }\end{array}$ \\
\hline No. 5 & $\begin{array}{l}\text { 左 側 } \\
\text { 右 側 }\end{array}$ & $\begin{array}{l}( \pm) \\
( \pm)\end{array}$ & $\begin{array}{l}( \pm) \\
( \pm)\end{array}$ \\
\hline No. 6 & $\begin{array}{l}\text { 左 側 } \\
\text { 右 側 }\end{array}$ & $\begin{array}{l}( \pm) \\
( \pm)\end{array}$ & $\begin{array}{c}\text { 左向き, 振门小または中等度, 中頻度 } \\
( \pm)\end{array}$ \\
\hline No. 7 & $\begin{array}{l}\text { 左 側 } \\
\text { 右 側 }\end{array}$ & $\begin{array}{l}( \pm) \\
( \pm)\end{array}$ & $\begin{array}{l}( \pm) \\
( \pm)\end{array}$ \\
\hline No. 8 & $\begin{array}{l}\text { 左 側 } \\
\text { 右 側 }\end{array}$ & $\begin{array}{l}( \pm) \\
(-)\end{array}$ & $\begin{array}{l}(-) \\
(-)\end{array}$ \\
\hline No. 9 & $\begin{array}{l}\text { 左 側 } \\
\text { 右 側 }\end{array}$ & $\begin{array}{l}( \pm) \\
( \pm)\end{array}$ & $\begin{array}{c}( \pm) \\
\text { 右向き，振巾中等度，小頻度 }\end{array}$ \\
\hline
\end{tabular}




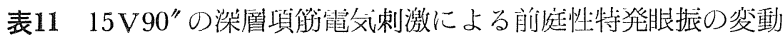

\begin{tabular}{|c|c|c|c|}
\hline \multirow{2}{*}{$\begin{array}{c}\text { 動 物 } \\
\text { (左側末梢 } \\
\text { 迷路破壊) }\end{array}$} & \multirow{2}{*}{ 刺激側 } & \multicolumn{2}{|r|}{ 前 庭 性 特 発 眼 振 } \\
\hline & & 刺 激 前 & 剌 激 後 \\
\hline No. 10 & $\begin{array}{l}\text { 左 側 } \\
\text { 右 側 }\end{array}$ & $\begin{array}{l}( \pm) \\
( \pm)\end{array}$ & $\begin{array}{c}\text { (一) } \\
\text { 右向き, 振巾中等度, 小頻度 }\end{array}$ \\
\hline No. 11 & $\begin{array}{l}\text { 左 側 } \\
\text { 右 側 }\end{array}$ & $\begin{array}{l}( \pm) \\
(-)\end{array}$ & $\begin{array}{l}\text { 右向き，振币小，中頻度 } \\
\text { 右向き，振币小，きわめて高頻度 }\end{array}$ \\
\hline No. 12 & $\begin{array}{l}\text { 左 側 } \\
\text { 右 側 }\end{array}$ & $\begin{array}{l}( \pm) \\
( \pm)\end{array}$ & $\begin{array}{c}\text { 右向き, 振巾小または中等度, 小頻度 } \\
( \pm)\end{array}$ \\
\hline No. 13 & $\begin{array}{l}\text { 左 側 } \\
\text { 右 側 }\end{array}$ & $\begin{array}{l}(-) \\
(-)\end{array}$ & $\begin{array}{l}\text { 右向き, 振巾中等度, きわめて高頻度 } \\
\text { 右向き, 振巾中等度, 小頻度 }\end{array}$ \\
\hline No. 14 & $\begin{array}{ll}\text { 左 } & \text { 側 } \\
\text { 右 } & \text { 側 }\end{array}$ & $\begin{array}{l}( \pm) \\
( \pm)\end{array}$ & $\begin{array}{l}( \pm) \\
( \pm)\end{array}$ \\
\hline No. 15 & $\begin{array}{l}\text { 左 側 } \\
\text { 右 } \text { 側 }\end{array}$ & $\begin{array}{l}(-) \\
( \pm)\end{array}$ & $\begin{array}{l}(-) \\
( \pm)\end{array}$ \\
\hline No. 16 & $\begin{array}{l}\text { 左 側 } \\
\text { 右 側 }\end{array}$ & $\begin{array}{l}( \pm) \\
(-)\end{array}$ & $\begin{array}{c}\text { 右向き，振门中等度，小徏度 } \\
(-)\end{array}$ \\
\hline No. 17 & $\begin{array}{l}\text { 左 側 } \\
\text { 右 側 }\end{array}$ & $\begin{array}{l}( \pm) \\
(-)\end{array}$ & $\begin{array}{l}(-) \\
(-)\end{array}$ \\
\hline No. 18 & $\begin{array}{l}\text { 左 側 } \\
\text { 在 側 }\end{array}$ & $\begin{array}{l}(-) \\
( \pm)\end{array}$ & $\begin{array}{l}(-) \\
( \pm)\end{array}$ \\
\hline
\end{tabular}

術後日を経たものでは, 術側向きの水平性眼振 が誘発されやすい事実をも明らかにしている （福井 1971, 福井ら 1970). 今回私達の得た成 績も，福井の成績と相似している．以上のウサ ギの成績から推論できるととは, 片側内耳障害 があらかじめ存する場合, 頸笳緊涱元進は内耳 障害型平衡障害を誘発する傾向があるというこ とであろう。そしてての成績はまた同時に，上 述の私達の考えに有力な資料を提供している点 で注目に值する.

以上，1），2），3）にあげた成績より， 私達は改めて次の考えを申し述べておきたい。 すなわち，むち打ち機転が正常人に加わる場 合, 内耳障害型平衡失調や内耳性「めまい」は 容易には成立しない。ただし，受傷に先んじて 内耳に機能的ゼイ弱性が存するかまたは内耳に 疾患が存する場合は，むち打ち機転による頸部

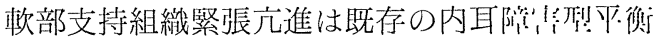
失調を manifest とし，乙れに由来して頸耳性 「めまい」がおてる。この考えは，桧らが頸部 軟部支持組織緊張亢進と中枢神経系，とくに脳 幹，小脳の障害が互いに「引き金」と「まと」 の関係をなして「めまい」を構成するという考 えに原則的にあてはまり，またその考光の妥当 性を更に拨大した点で注目されてよい。

\section{（3）中枢神経の線維連絡からみたむち打ち} 損傷例にみられる内耳性「めまい」発現機序：

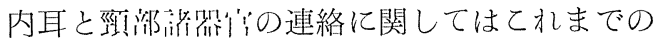
研究は主として頸部交感神経と内耳機能の関係 について述へらら扎抽，乙こで問題にしてい るような頸部深部受容器との関係については触 れられることが少なかった。しかし上述したよ うな成績より案ずると, 頸部深部受容器と前庭 迷路系!上㙨能们沅も深い連関を有するものと考 
えられる.さて片側内耳の機能，とくにその平 衡機能と頸部深部受容器が関連するとすると, 次の $2 つ の$ 様式が想定される。その一つはneural mechanism を介して両者が協応する場合と， 他は neuro-vascular mechanism を介してそ れを行なう場合とであろう。乙の問題を中枢神 経の線維連絡の立場から考察してみよう。

1 ) 先ず neural mechanism の観点からて の問題をとりあげてみたい. 周知のように，頸 部深部受容器は脊髉後根を介して頸髄中に入る が，頸髄から脳幹を上行する途上で前庭迷路第 一次終止核と連絡する。 その様式に関しては次 の roots があげられる. spinoreticular tract $\rightarrow$ Deiters 核 $\rightarrow$ 前庭神経内側核 $\rightarrow$ FLM $\rightarrow$ 眼球運動核である。新見によると， spinoreticular tract は主として延髄，橋，網様体に終 止し，その一部则脳綃栤低に達するという。

そしてての上行線維は Deiters 核とも連絡を有 するといわれている（新見ほか 1968）。さて Deiters 核の刺激実験や破壞実験でも眼振はお こるとされているが，水平性眼振が典型的に成 立するのは前庭神経核の中でも内側核の刺激ま たは破壊であるととか知られている(Monnier 1970)。Deiters 核と前庭神経内側核との連絡 についてはな打滺が残されているとはいえ，

Cajal は, Deiters 核とくにその大細胞は dendrite をもって内側核と連絡するという (Cajal 1909). また，Lorente de Nò によると，Dei-

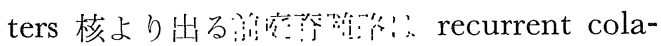

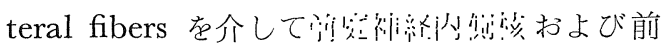
庭神経下核と連絡すると述べている (Lorente de Nò 1953). そして Brodal らは上述の spinoreticular tract , 直接前庭神経内側核 および下核との連絡があるという (Brodal et al. 1962). このように考えると: 頸部深部受容 性インパルスは spinoreticular tractにつたえ られ，Deiters 核を介しまたはてれを介さずし

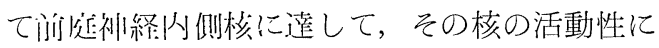
影響をあたえる可能性は立分にあってよい。

さて片側の前庭迷路が破壊された場合には，
てれまでの種々の報告を参照すると，左右前庭 神経核に活動性の不均衡が生ずるはずであり, その表示の一つが特発眼振である.ささてての腿 振は時間を経るに従って消祀退するが，その機序 は最終的には両側前庭神経核（とくに水平性眼 振については内側核であろう) の活動性の均衡 化に上ると考えてよからう。 今もし，そのよう にして辛じて均衡を保っている前庭神経核に対 して, 深部受容器からのインパルスが新しく加 えられると, 両側前庭神経核間の均衡が再び破

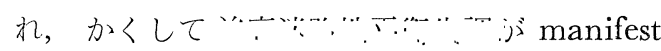
となる．乙の際, 中枢神経系内での両側前庭神 経核間の均衡化は一方向的には進行せず，丁度 科のつり合い運動のように，右または左の前庭 神経活動性の優位がひきおてされつつ, 最後に は両者がつり合うことになるものと考えられ る。そしててのような機序があるゆえに，例え ば同じ深層項筋への刺激で，ある時期では健側 向きの水平性眼振が，またある時期では手術側 向きの水平性眼振が誘発されるものと考えられ る.上述したむち打ち損傷による内耳障害型平 衡失調や耳性「めまい」例の平衡障暃が，頸部 有痛部に低周波刺激を加えるととにより manifest となるメカニズムも，同じような考えで律 してよからう。なぜなら，ヒトにおいても只今 述べたような中枢神経の線維連絡か源則的に肯 定されているからである.

2）他の一つひ機泞は neuro-vascular mechanism により頸部深部受容器が内耳に影響 をあたえる機序であろう。

頸部深部受容器から上行する線維, 例えば上

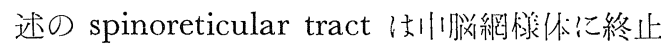
するほか，中脳中心灭白質にも終止するてとが 知られている（新見 1970）。そしてての部位か

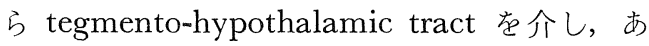
るいはてれを介さずして視床下部に達する。ま た視床下部よりは遠心性自律神経線維，たとえ ば，Schütz 电师侧綐來が下行するが，乙れが 延髄血管中枢に影響をあたえる可能性は充分に あってょい，てのほかに中脳中心灭白質に達し 
た段階で，遠心性自律神経線維に連繫する連絡 様式ももちろんあってよい（新見 1970）。そし

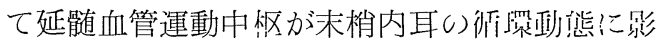
響をおよぼし，てれにもとづいて内耳性平衡機 能変動がおこるメカニズムが存するてとは,

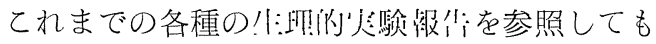
納得できる。私達は，頸性におてる内耳性「め

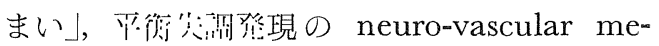
chanism には以上のような機序もふくまれて
よいと考えている。もちろん，頸部軟部支持組 織緊張元進でおこる内耳性「めまい」, 平衡失 調が以上のいずれの機序を介して成立するかの 詳細は今後し河能である。しかし，頸部軟部支 持組織緊張穴進で，雨衡㙨拕の変動が，蝸牛系 の機能のそれに比して，より明膫におてる自験 よりすると，少なくとも前者の機序は重視さる べきものと考えている.

\section{IV む す び}

（1）むち打ち椇傷例では，回転性「めまい」，非回転性「めまい」抢よび両者を合併するものい ずれも存した，回転性「めまい」は非回転性「めまい」に比し，その出現頻度が低かった．平衡機

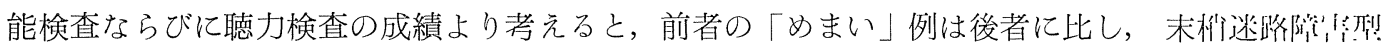
平衡失調を示す頻度が高かった。

（2）回転性「めまい」例でも項部痛をともなうととが多い。また，てれらの例の項部有痛部に

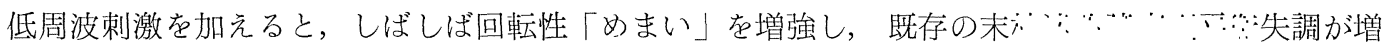
大した.なお，項部痛をともなう非外傷性耳性「めまい」例に同じ項部低周波刺激を行なったとて ろ，むち打ち損傷による回転性「めまい」例で得た成績と相似する成績を得た。これらの成績は， “むち打ち損傷による内耳障害型「めまい」，平衡失調认䣆激忺蔀支持組織緊張元進により誘発され る”との考えを支持している.

（3）受傷に先行して内耳の機能にゼイ弱性が存することが，むち打ち機転で内耳障害型「めま い」，平衡失調の発現を促進する一原因と考えられる．ての考えをウサギを用いて明らかにした．す なわち，正常ウサギではその片側深層項筋に比較的強い電気刺激を加えても眼振はみられない，し かし，片側末梢迷路を破壊したウサギの同じ项伤に西父傐激を加えると，潜在性となった眼振が高 率に誘発される事実が判った。

㪁帛大学医学部耳鼻咽堠科学教室福田精教授, 御退官にあたり,この諭文を捧げます。

稿を終るにあたり，中怄神経系の線維連絡についての知見を御教示いただいた岡山大学解剖学教室新見嘉兵衛 教授に深謝します。また以上の報告にもられた成績は, 德島大学医学部耳鼻咽㟙科学教室および徳島市民病院（医 長：多田嘼溥士）の協同研究者の努力によるもので，各位に感謝します，

\section{参考文 献}

1) Brodal, A., Pompeiano, O. and Walberg, F. : The Vestibular Nuclei and their Connections, Anatomy and Functional Correlations. Oliver and Boyd., 1962. Git. by 新見嘉兵衛 : Personal Communication, 1973.

2) Cajal S.R. Ramón, Y. : Histologie du Système Nerveux de I'Homme et des Vertébrés. Maloine, Paris, Git. by 䉼見嘉兵衛 : Personal Communi- cation, 1973.

3) 福井堅二, 桧学, 牛尾信也：深部受容器之前庭性: 平衡失調一片側前庭迷路破溒门サギを対象とする 観察—. 第27回日本平衡神経科学会プログラム。 测浱抄録集: 16〜 17，1970.

4) 福井堅二 : 頸部, 腰部深部受容器と前庭性平衡失

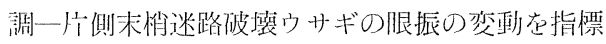
上する観察—. 耳鼻酄床 $64 ； 8: 803 \sim 829$, 
1971.

5）日根其二, 桧 学, 他 : 頸性「めまい」発現に 関する研究一項部低周波刺激による平衡機能と聴 力像の変化を指標とする観察一，第20回日本前庭

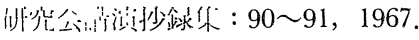

6）日根其二：蝸牛症状を欠く回転性メマイ発作一頸 反射障害を中心に一。平衡神経科学 $30: 77$ 78,1972 .

7) Hinoki, M. and Terayama, K. : Physiological Role of Neck Muscles in the Occurrence of the Optic Eye Nystagmus. Acta Otolaryng. (Stockh.) $62: 157 \sim 170,1966$.

8）桧学, 寺山邦昭, 他: 頭部外笏における頸性 「めまい」発現機転に関する考察．耳鼻臨床 60 ; 增 1：14〜37，1967.

9）桧学：いわゆるむち打ち損傷による「めま い」発現機転と治療に関する考察. 耳鼻臨床 62 ; $4:$ 359〜375, 1969.

10）桧学: 外慯性頸，腰性めまい一めまい構成に おける Proprio-ocular Reflex, Proprio-spinal Reflex と Proprio-vegetative Reflex の関連一. 臨床と研究 $48 ； 11 ： 112 \sim 121 ， 1971$.

11）朴沢二郎：眩暈症の治療一手術的立場から一。耳 㽰 $37 ; 7: 625 \sim 633,1965$.

12）石田美夫：Cervico-Muscular Vertigo 成立機転 に関する実験的研究；むち打ち損傷例のめまい, 平衡失調成立機序解明への一つの approach. 日 耳鼻会報 $75 ； 12 ： 1422 \sim 1455 ， 1972$.

13）小池聰之，桧 学: 末梢迷路障害型平衡失調発 現における頸部深部受容器の役割に関する実験的 研究一むち打ち損傷列の末悄迷路性めまい発現機 序解明への 1 つの approach一. 第 2 回中四国脳・ 神経外傷研究会 : 10, 1971.

14) Lorente de Nò : Vestibulo-ocular Reflex Arc. Arch. Neurol. Psychiat. (Chicago) $30: 245$,
1933. Cit. by 新見嘉兵衛 : Personal Communication, 1973.

15) Maspetiol, R.： 障害とその治療 (牟田訳)。耳喉科 32：939 944, 1960.

16）三浦幸雄，他：実験的むち打古損傷，墨汁注入愫 本よりみた脳，脊喊の動静脈系の態度について， シンポジゥム「缏打ち損傷」、第27回脳神経外科 学会総会誌 (東京) : 1968. Git. by 坂田英治, 他 : いわゆる「鞭打ち損傷症」の成因に関する新し い考元方，災害医学 $12 ： 830 ， 1969$.

17）三浦幸雄，田中峯 : 実験的むち打ち損傷における 頭，頸部の静脈の態度．脳，神経外傷 $2: 217$, 1970.

18) Niimi, K., Fujita, S., et al. : An Experimentalanatomical Study on the Spinothalamic Tract in the Cat. Okajima Fol. Anat. Jap. 44 : 255, 1968.

19）新見嘉兵衛 : Personal Communication, 1970.

20）零 俊一：神経耳科の立場からみたむち打ち損傷 による蝸牛症状．耳鼻臨床 $66: 8 ; 813 \sim 863$, 1973.

21）時田 喬：メ二エル氏病の背景.耳鼻臨床 58 ; $4: 190 \sim 205,1965$.

22) Wildhagen, F.K. : Mènière Syndrom bei Affektionen der Oberen Halswirbelsäule. Arch. Ohren-u.s.w. Heilk. 159 : 242, 1951.

23) Wildhagen, F.K. : Ein klinischer Beitrag zur Pathogenese Hydropischer Innenohrprozesses. Acta Otolaryng. 49 : 256 269, 1958.

\footnotetext{
$\left(\begin{array}{l}\text { 原稿 到着: 昭和 } 49 \text { 年 } 8 \text { 月 } 22 \text { 日 } \\ \text { 別刷請求先: 日根其二 } \\ \text { 婹 } 770 \text { 徳島市蔵本町 } 3 \text { 丁目 } 50 \text { 番地 } \\ \text { 徳島大学医学部耳舅咽喉科学教室 }\end{array}\right)$
} 